\title{
FEATURE Toward a collaborative approach to watershed management: Lessons learned from the Boone River Watershed, lowa
}

\author{
Stephanie K. Enloe, Lisa A. Schulte, and John C. Tyndall
}

W ater quality degradation is a problem of local and national concern. Nutrients, sediment, and bacteria from nonpoint agricultural sources pose a public health risk, reduce biodiversity, and contribute to hypoxic conditions in the Gulf of Mexico. For decades, agricultural communities have struggled to manage nutrient and soil loss, but public concern over water quality has led to enhanced efforts to build innovative watershed management programs.

The Boone River Watershed (BRW) initiative in north central Iowa, United States, is a large, multistakeholder effort to design a scalable system of adaptive watershed management. Program partners include environmental and agricultural organizations from public, private, and nonprofit sectors. These groups collaborate to improve environmental performance on multiple scales while preserving farmer well-being. Partners' dedication to a watershed-wide, multiscale monitoring program and to working with local farmers has enabled them to target solutions, leverage funding, and engage new stakeholders.

In 2012, partners commissioned a three-part science evaluation to measure biophysical and socioeconomic indicators of success, identify remaining barriers, and offer recommendations for future program outputs. Our team conducted a third-party evaluation of social dynamics in the BRW to provide insight on improving partner alignment and farmer engagement. Here we present findings and recommendations useful to other agricultural watershed management efforts.

\section{BACKGROUND}

Iowa has been at the forefront of agricultural pollution problems for decades. As

Stephanie K. Enloe received her Master of Science in Sustainable Agriculture from lowa State University, Ames, lowa. Lisa A. Schulte is an associate professor, and John C. Tyndall is an assistant professor in the Department of Natural Resource Ecology and Management at lowa State University, Ames, lowa. of April, 2012, there were 480 water bodies on the state's 303(d) impaired waters list (IDNR 2012), and agricultural pollutants in the form of excess bacteria, nutrients, and sediment contribute significantly to those impairments. Iowa also supplies a large percentage of the excess nutrients that cause hypoxia in the Gulf of Mexico (Alexander et al. 2008; David et al. 2010). Row crop agricultural practices collectively are among the main drivers of water quality degradation in Iowa, in large part because agricultural land accounts for 12.4 million ha $(30.7$ million ac), or about $86 \%$, of the state's land cover (USDA NASS 2014). Nutrients such as nitrogen $(\mathrm{N})$ and phosphorous $(\mathrm{P})$ are applied as fertilizer and lost through leaching, surface runoff, and erosion. An estimated $52 \%$ of the $\mathrm{N}$ and $25 \%$ of the $\mathrm{P}$ reaching the Gulf of Mexico is lost from corn (Zea mays L.) and soybean (Glycine max L.) systems located in the Mississippi River Basin (Alexander et al. 2008).

In response to the 2008 Gulf Hypoxia Action Plan (USEPA 2008) to improve water quality in the Mississippi River, Iowa conducted a science assessment and developed a statewide strategy to improve surface water quality. The Iowa Nutrient Reduction Strategy calls for a $41 \%$ reduction in $\mathrm{N}$ export and $29 \%$ reduction in $\mathrm{P}$ export from Iowa farms (Iowa 2013). The strategy presents state-wide management scenarios that could lead to reduction goals, but farmer compliance with the strategy is voluntary.

Although the Nutrient Reduction Strategy is voluntary, farmers and agribusiness organizations face pressure to demonstrate improvements in water and soil conservation. Complex economic, agronomic, and social factors, however, make it difficult for watershed practitioners to engage farmers in water quality outcomes (Baumgart-Getz et al. 2012; Reimer et al. 2012). To overcome barriers to water quality management, government agencies employ cost-share and technical assistance to incentivize farmers to adopt practices aimed at soil and water conservation.
For water quality management programs to be effective- both in terms of costs and biophysical outcomes-research suggests farm-level outputs must be coordinated with implementation, monitoring, and evaluation at watershed scales (Wortmann et al.2008; Morton and Brown 2011; Rickenbach et al. 2011; Tomer et al. 2013). Although watershed boundaries do not correlate with sociopolitical boundaries (Atwell et al. 2009), managing according to ecological boundaries allows watershed practitioners to target resources to the most vulnerable parts of the landscape (Legge et al. 2013). Additionally, water quality monitoring data collected at the field, tile-shed, subbasin, and watershed scales enable practitioners to evaluate how agricultural pollutants behave over multiple spatial and temporal scales. Coordinating farm-level outreach with watershed goals helps stakeholder groups engage in water quality management at multiple social-ecological scales.

To link monitoring, targeting, and outreach efforts, natural resource management programs increasingly employ adaptive management (Allen et al. 2011; Herrick et al 2012) — an "iterative decision-making process that incorporates formulation of management objectives, actions designed to address those objectives, monitoring of results, and repeated adaptation of management until desired results are achieved" (Herrick et al. 2012). This form of experimental management is well-suited for complex social-ecological systems characterized by uncertainty (PahlWostl et al. 2007).

As Iowa watershed programs shift to an adaptive, targeted approach, they also are moving toward diversified stakeholder collaborations (Morton and McGuire 2011; Comito et al. 2013). Watershed projects have begun to attract stakeholders from the business, nonprofit, and public sectors and to gain success through collaborative management (Moore and Koontz 2003; Bidwell and Ryan 2006). Public-private partnerships create more opportunity for watershed managers to target vital parts of the landscape, avoid 


\section{Figure 1}

Map of the Boone River Watershed in lowa. The Boone River Watershed is an eightdigit hydrologic unit code (HUC-8) watershed containing 30 HUC-12 sub-basins. Lower Eagle, Buck, and Lyons creeks are highlighted in light blue.

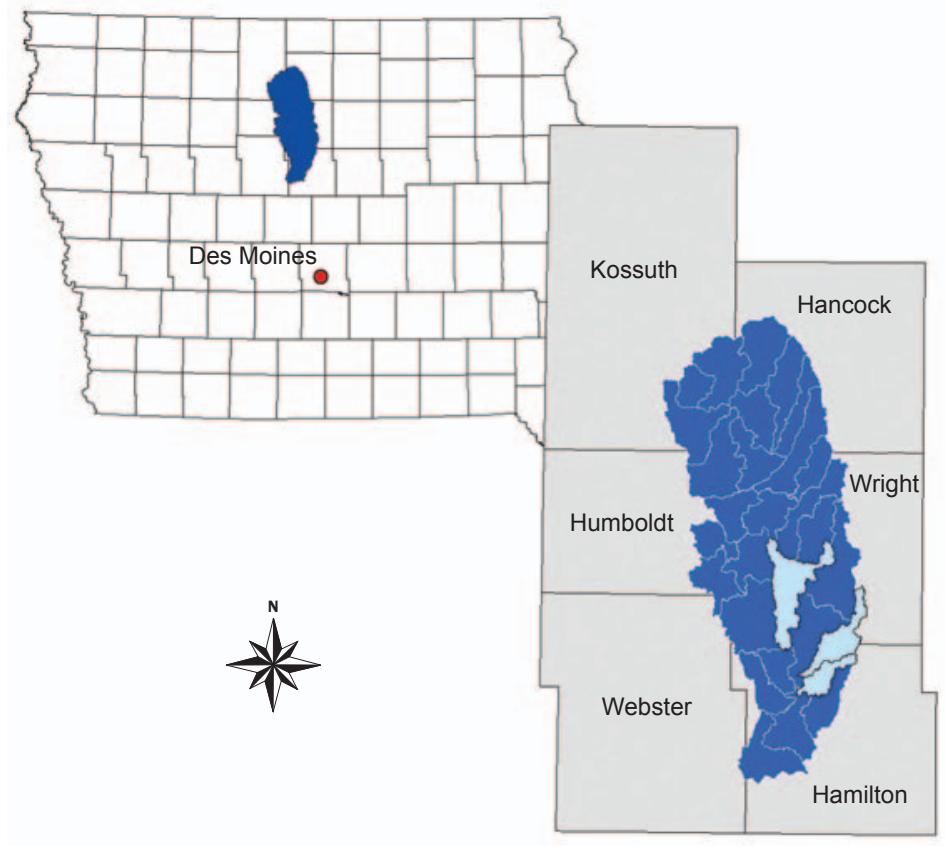

overlapping or contradictory outputs, reach more farmers, and leverage new sources of funding (Morton and McGuire 2011; Hanleybrown et al. 2012). As the majority of multistakeholder watershed programs are in their infancy, however, questions remain about how best to organize these initiatives (Plummer 2009).

\section{THE BOONE RIVER WATERSHED PROGRAM}

The BRW is an eight-digit hydrologic unit code (HUC-8) watershed and contains 30 smaller, HUC-12 subbasins (Blann 2008) (figure 1). It spans 237,000 ha $(585,600$ ac) over six Iowa counties on the Des Moines Lobe (Blann 2008), a region of central Iowa known for rich glacial soils, gentle slopes, and high agricultural productivity. Nearly $99 \%$ of the watershed is privately owned, and more than $90 \%$ of the land is in agricultural production (USDA NRCS 2008). Corn, soybeans, hogs, and poultry are the primary agricultural enterprises in the area.

Prior to settlement, the BRW was poorly drained wetland with morainal soils and interconnected prairie potholes (Prior 1991). Today the hydrology is influenced by extensolutions to water quality problems.
Additional organizations have joined the BRW partnership to work toward a common goal of maintaining agricultural production while protecting water quality. Partners have been able to leverage a number of federal and private grants to implement an adaptive management program in the BRW. Program leaders work with farmers to implement in- and edgeof-field practices such as strip-till, cover crops, denitrifying bioreactors, and nutrient management.

In our third-party program evaluation, we sought to understand decision-making processes and stakeholder communication in the BRW. To achieve this objective, we conducted and analyzed 33 semistructured interviews with BRW stakeholders, including program partners, farmers, technical service providers, and agribusiness retailers. We selected respondents based on nonprobability sampling methods, which provided us with a diverse range of perspectives on program management, outputs, and objectives (Neuman 2013). Primary interview data were triangulated against BRW documents, such as grant applications, progress reports, and outreach materials (Esterburg 2002). We used a grounded theory methodology (Strauss and Corbin 1990) to answer the following research questions:

- What progress have partners made toward their stated outcomes?

- What are the remaining barriers to fulfilling program objectives?

- What recommendations do BRW stakeholders have for how to improve the program?

- What lessons can be learned from other successful watershed initiatives?

Our evaluation highlighted program successes, remaining gaps, and allowed for a prioritization in the context of recommendations presented to BRW organizational partners. All recommendations were informed by interview data, research conducted in other watersheds, and literature on organizational management. goals were to determine how agricultural practices influence water quality on watershed, subwatershed, and field levels, and to develop and implement science-based 
Findings are organized under three lessons that emerged from data collection and analysis.

Lesson One: A Multiscale Monitoring and Evaluation System Is a Foundation upon which Diverse Watershed Stakeholders Can Base Adaptive Management. The BRW water monitoring network and field-level data form the foundation for multiscale adaptive management. To monitor nitrate $\left(\mathrm{NO}_{3}\right), \mathrm{P}$, and cyanobacteria, partners collect biweekly grab samples and storm event samples from several sites along the main stem of the Boone River, at the end of each HUC-12 tributary, and at the subbasin level in Lyons Creek. Water monitoring data help partners understand the causes of water quality problems, target areas that contribute most heavily to nutrient loading, evaluate the efficacy of best management practices (BMPs), and write and carry out management plans that link fields and farm systems to their immediate basin and then to the broader watershed. Partners cite evidence from the water monitoring network and watershed plans to attract additional private and public funding. Because partners identified several HUC-12s with high $\mathrm{NO}_{3}$ levels, they have been able to attract additional funds to write watershed plans and conduct outreach in those watersheds.

To compare water quality data to land management, partners also work with farmers to collect water quality and agronomic data at the field level. Farmer and agronomist respondents indicated that data from stalk $\mathrm{NO}_{3}$ sampling, tissue and soil testing, and bioreactor or tile line sampling allow them to modify management plans to reduce nutrient and soil loss. Where applicable, bioreactor and tile line data help farmers gauge their contribution to water quality problems and better manage nutrients. One farmer highlighted the importance of individualized data when he stated, "Working with [program leaders], that's given me a lot more insight than I would have had otherwise, and it encourages me to keep doing what I'm doing. I think that if other farmers knew that their water was high in nitrates they might think, 'well, maybe I am part of the problem,' but most people don't know that."
Several farmers in the BRW were unaware of the opportunity to conduct tile line sampling; however, these same respondents indicated they would be interested in implementing the practice if they can trust that data will remain confidential.

Given that a credible, multiscale water quality monitoring and evaluation system provides the foundation for evaluation and learning at all levels, we recommend that efforts to assemble such systems be prioritized by watershed groups and funders. Furthermore, as a watershed is a socialecological system, we recommend that a monitoring and evaluation network measure and use social as well as ecological data to target areas and improve outreach. The Social Indicators Planning and Evaluation System outlined by Genskow and Prokopy (2008) is an example of a social monitoring system that could be used to measure social dynamics in watersheds such as the BRW; Knoot et al. (2014) provide another, simpler framework. Ecological and social monitoring should take place at field, tile-shed, subbasin, and watershed scales to personalize data for all program participants and guide adaptive planning and outreach by program partners. If possible, baseline data should be collected in the first stages of program development. Watershed programs should also make an effort to provide interested farmers with environmental and agronomic data that can help guide management decisions. Personalized data should be presented by a trusted source and interpreted in ways that are meaningful to farmers.

Lesson Two: Strong Relationships with Farmers Are Vital to Program Success. If watershed efforts are to succeed in the long term, farmers and landowners must share the common vision of multibeneficial agricultural systems that protect natural resources while providing food. While the adoption literature offers insight into farmer decisionmaking processes (Rogers 2010; Pannell et al. 2006; Prokopy et al. 2008; Baumgart-Getz et al. 2012; McGuire et al. 2013; Reimer et al. 2012), researchers and practitioners continue to struggle with how best to engage farmer stakeholders (Prokopy et al. 2008; Baumgart-Getz et al. 2012; McGuire et al. 2013; Reimer et al. 2012)
The diffusion of innovations theory suggests a technology or idea is more likely to spread if local opinion leaders publicly support the innovation (Rogers 2010), and our data support this theoretical claim. Program partners in the BRW identified a handful of current or potential "farmer champions" who promote BMPs and help other farmers learn to manage new practices. The majority of farmer respondents spoke highly of these champions, and there is evidence that certain practices are diffusing more rapidly because of their influence. One farmer respondent stated, "I think we're becoming much more comfortable around here with strip till. We're hearing another neighbor or hearing somebody - particularly a farmer that is considered to be a good farmer. If we get a few of those guys strip tilling it suddenly becomes a little more acceptable."

Farmer respondents from the BRW were also more likely to try a new BMP if they had a trusting relationship with one or more program leaders. Farmers in the BRW named a handful of program staff with whom they have close relationships; these same individuals were particularly effective at engaging farmers to try a new practice.

Because relationships play such a large role in farmer engagement with water quality management objectives and outputs, we recommend that watershed programs prioritize building social capital in agricultural communities. To do so, they must hire and train personnel who are engaged in outreach for prolonged periods of time. Additionally, watershed partners should intentionally cultivate leadership among conservation-minded farmers with high social capital. Outreach and training for farmer leaders should be a strategic element of watershed program outputs.

Lesson Three: Multistakeholder Watershed Initiatives Would Benefit from a Transparent Backbone Structure to Streamline Collaboration and Communication. A primary gap we identified in the BRW program was the lack of a coordinated communication system. As of 2012, interorganizational communication was dependent upon relationships between program leaders. Several respon- 
dents indicated they would like to form a backbone organization to ensure all groups maintain focus, create opportunities for brainstorming and creative problem solving, and help leverage additional funding. Attendees at a 2013 stakeholder meeting expressed great interest in more regular meetings, as they were able to generate many ideas in a short time when given the opportunity to have an unhurried roundtable discussion.

We also identified a communication gap between program personnel and farmers. Although program partners have amassed data that indicate $\mathrm{NO}_{3}$ loading is clearly an agricultural problem in the BRW, no particular group has taken the responsibility to communicate the results of water monitoring data with farmers. Our findings suggest many BRW farmers are unsure of the severity and/or causes of nutrient and sediment pollution in their region; if these data were clearly communicated, they could be a source of motivation for farmers. One farmer respondent said, “[Brian] shared a little bit of [the BRW water monitoring data] with me. Yeah we're... he's finding that [nitrate] is getting in there. And the amount shocked me that I've seen from him. So we need to do better."

Because water quality data have the potential to dispel misconceptions about the existence or severity of water quality issues, we recommended that partners make multilevel data a key element of their outreach efforts.

Based on the size of the effort and identified gaps, we recommended that BRW partners would benefit from a coordinating entity. An independently staffed backbone organization would implement organizational processes to support strategic collaboration and facilitate the adaptive management process. The backbone organization would conduct tasks necessary to program success that are not the responsibility of any one program partner. For example, the organization could coordinate stakeholder meetings; coordinate an outreach and marketing campaign to fill communication gaps with farmers; implement evaluation processes that address collective effort rather than outputs from certain organizations; and identify and engage additional partners to fill program- matic gaps. One model we recommended was the collective impact model, described by Kania and Kramer (2011).

\section{CONCLUSION}

For the past 10 years the BRW has been the focus of significant monitoring, planning, outreach, and funding efforts. Program partners and funders believe investments in the BRW will not only yield improvements to local water quality, but help refine a framework that can ultimately be transported to other watersheds. Because water quality responds slowly to changes in land management, there are still too few years of monitoring data to detect significant nutrient reductions at the watershed scale. However, partners have demonstrated progress toward near-term outcomes that may lead to long-term water quality objectives.

BRW partners have shown how multisector collaboration can strengthen midterm outcomes such as the ability to leverage resources, engage farmers in program outputs, and use data to guide adaptive decision making at multiple scales. Partners have also demonstrated how water monitoring data can be used to direct resources to key parts of the watershed, leverage grant funding, and shift farmers' perceptions of water quality and management practices. Progress in the BRW indicates that other groups may benefit from building diverse partnerships, investing in water quality monitoring, engaging in watershed planning, and fostering strong relationships with farmers.

While BRW partners are on track to meet a number of near-term goals, we identified some programmatic gaps that could serve as barriers to meeting long-term objectives for water quality improvement. Many of the identified gaps could be filled by creating an independent backbone organization to guide the collaborative efforts. While more thought, effort, and time is needed to understand how to best organize a backbone structure for a large agricultural watershed program, the collective impact model for social change offers a compelling framework for experimentation (Kania and Kramer 2011).

\section{REFERENCES}

Alexander, R.B., R.A. Smith, G.E. Schwarz, E.W. Boyer, J.V. Nolan, and J.W. Brakebill. 2008. Differences in phosphorous and nitrogen delivery to the Gulf of Mexico from the Mississippi River Basin. Environmental Science and Technology 42(3):822-820.

Allen, C.R., J.J Fontaine, K.L Pope, and A.S. Garmestani. 2011. Adaptive management for a turbulent future. Journal of Environmental Management 92:1339-1345.

Atwell, R.C., L.A Schulte, and L.M. Westphal. 2009. Landscape, community, countryside: Linking biophysical and social scales in US Corn Belt agricultural landscapes. Landscape Ecology 24:791-806.

Baumgart-Getz,A., L.S. Prokopy, and K. Floress. 2012. Why farmers adopt best management practices: A meta-analysis of the adoption literature. Journal of Environmental Management 96:17-25.

Bidwell, R.D., and C.M. Ryan. 2006. Collaborative Partnership design: The implications of organizational affiliation for watershed partnerships. Society and Natural Resources 19:827-843.

Blann, K. 2008. Boone RiverWatershed Conservation Action Plan. Iowa:The Nature Conservancy.

Comito, J., J. Wolseth, N. Stevenson, and C. Brown. 2013. Black Hawk Lake Watershed Assessment and Outreach Campaign. Ames, IA: Iowa State University Extension. http://www.extension. iastate.edu/ilf/sites/www.extension.iastate.edu.

David, M.B., L.E. Drinkwater, and G.F. McIsaac. 2010. Sources of nitrate yields in the Mississippi River Basin. Journal of Environmental Quality 39(5):1657-1667.

Esterberg, K.G. 2002. Qualitative Methods in Social Research. Boston: McGraw-Hill.

Genskow, K., and L. Prokopy. Eds. 2008. The Social Indicator Planning and Evaluation System (SIPES) for Nonpoint Source Management: A Handbook for Projects in USEPA Region 5: Version 2.0. Great Lakes Regional Water Program.

Hanleybrown, F., J. Kania, and M. Kramer. 2012. Channeling change: Making collective impact work. Stanford Social Innovation Review 10th Anniversary Edition:1-8.

Herrick, J.E., M.C. Duniway, D.A. Pyke, B.T. Bestelmeyer, S.A. Wills, J.R. Brown, J.W. Karl, and K.M. Havstas. 2012. A holistic strategy for adaptive land management. Journal of Soil and Water Conservation 67(4):105A, doi:10.2489/ jswc.67.4.105A.

Iowa. 2013. Iowa Nutrient Reduction Strategy: A science and technology-based framework to assess and reduce nutrients to Iowa waters and the Gulf of 
Mexico. Ames, IA: Iowa Department of Agriculture and Land Stewardship, Iowa Department of Natural Resources, and Iowa State University College of Agriculture and Life Sciences.

IDNR (Iowa Department of Natural Resources). 2012. Iowa's section 303(d) impaired waters listings. Des Moines, IA: Iowa Department of Natural Resources. http://www.iowadnr.gov/ Environment/WaterQuality/WaterMonitoring/ ImpairedWaters.aspx.

Knoot, T.G., GL.D. Larsen, and L.A. Schulte. So you need a social monitoring plan: Now What? Journal of Soil and Water Conservation 69(3):84A-88A, doi:10.2489/jswc.69.3.84A.

Kania, J., and M. Kramer. 2011. Collective Impact. Stanford Social Innovation Review (Winter):36-41.

Legge,J.T., P.J.Doran, M.E.Herbert,J.Asher, G. O’Neil, S. Mysorekar, S. Sowa, and K.R. Hall. 2013. From model outputs to conservation action: Prioritizing locations for implementing agricultural best management practices in a Midwestern watershed. Journal of Soil and Water Conservation 68(1):2233, doi:10.2489/jswc.68.1.22.

McGuire, J., L.W. Morton, and A.D. Cast. 2013. Reconstructing the good farmer identity: Shifts in farmer identities and farm management practices to improve water quality. Agriculture and Human Values 30(1):57-69.

Moore, E.A., and T.M. Koontz. 2003. A typology of collaborative watershed groups: Citizen based, agency-based, and mixed partnerships. Society and Natural Resources 16(5):45-460.

Morton, L.W., and S. Brown. 2011. Pathways to Better Water Quality. In Pathways for Getting to Better Water Quality:The Citizen Effect, eds. L.W.Morton and S. Brown. New York: Springer Science.

Morton, L.W., and J. McGuire. 2011. Getting to performance-based outcomes at the watershed level. In Pathways for Getting to Better Water Quality: The Citizen Effect, eds. L.W. Morton and S. Brown. New York: Springer Science.

Neuman, W.L. 2005. Social research methods: Quantitative and qualitative approaches. Boston: Allyn and Bacon.

Pahl-Wostl, C., J. Sendzimir, P. Jeffrey, J. Aerts, G. Berkamp, and K. Cross. 2007. Managing change toward adaptive water management through social learning. Ecology and Society 12(2):30.

Pannell, D.J., G.R. Marshall, N. Barr, A. Curtis, F. Vanclay, and R. Wilkinson. 2006. Understanding and promoting adoption of conservation technologies by rural landholders. Australian Journal of Experimental Agriculture 46:1407-1424.

Plummer, R. 2009. The adaptive co-management process: An initial synthesis of representative models and influential variables. Ecology and Society 14(2):24.

Prior, J.C. 1991. Landforms of Iowa. Iowa City, IA: University of Iowa Press.

Prokopy, L.S., K. Floress, D. Klotthor-Weinkauf, and A. Baumgart-Getz. 2008. Determinants of agricultural best management practice adoption: Evidence from the literature. Journal of Soil and Water Conservation 63(5):300-311, doi:10.2489/jswc.63.5.300.

Reimer, A., D.W. Weinkauf, and L.S. Prokopy. 2012. The influence of perceptions of practice characteristics: An examination of agricultural best management practice adoption in two Indiana watersheds. Journal of Rural Studies 28:118-128.

Rickenbach, M., L.A. Schulte, D.B. Kittredge, W.G. Labich, and D.J. Shinneman. 2011. Cross boundary cooperation: A mechanism for sustaining ecosystem services from private lands. Journal of Soil and Water Conservation 66(4):91A-96A.

Rogers, E.M. 2010. Diffusion of innovations. New York: Simon and Schuster.

Strauss A., and J. Corbin. 1990. Basics of qualitative research: Grounded theory procedures and techniques. Newbury Park: Sage Publications.

Tomer, M.D., S.A. Porter, D.E. James, K. Boomer, J.A. Kostel, and E. McLellan. 2013. Combining precision conservation technologies into a flexible framework to facilitate agricultural watershed planning. Journal of Soil and Water Conservation 68(5):113A-120A, doi:10.2489/jswc.68.5.113A.

USDA NASS (National Agricultural Statistics Service). 2014. Iowa Statistics. Des Moines, IA: USDA National Agricultural Statistics Service. http:// www.nass.usda.gov/Statistics_by_State/Iowa/.

USDA NRCS (Natural Resources Conservation Service). 2008. Boone River Watershed Rapid Watershed Assessment. USDA Natural Resources Conservation Service. http://www. nrcs.usda.gov/Internet/FSE_DOCUMENTS/ nrcs142p2_006983.pdf.

USEPA (US Environmental Protection Agency). 2008. Gulf Hypoxia Action Plan 2008. Environmental Protection Agency, Mississippi River Gulf of Mexico Watershed Nutrient Task Force. http://water.epa.gov/type/watersheds/ named/msbasin/upload/2008_8_28_msbasin_ gap2008_update082608.pdf.

Wortmann, C., M. Helmers, B. Gelder, L.W. Morton, D. Devlin, C. Barden, S. Anderson, R. Broz, T. Franti, T. Regassa, P. Shea, M. Tomer, L. Frees, and D. Griffith. 2008. Targeting of watershed management practices for water quality protection. Lincoln, NE: University of Nebraska-Lincoln Extension. 